\title{
5 \\ Un/deserving migrants and resisting dehumanisation
}

Satwinder: Those that are good people should be given a visa and those who are bad people should be returned.

(Ealing and Hounslow focus group, conducted by Sukhwant)

Satwinder is someone who migrated to the UK, and who talked to us about the unfair treatment and prejudice she had received since doing so. Yet, her views seem close to the stance taken by the Immigration Minister Mark Harper, quoted in the opening to Chapter 2. Satwinder spoke about herself as having 'earned the right to live or settle in Britain', and others as less deserving of that right. The difference from Harper's 'rational' distinction (based on legal definition) is that here the distinction is being made on openly moral judgements of whether people are 'good' or 'bad'. For Satwinder there are those 'that are working' (good) and there are those that 'get caught up in drink and drugs and should not be here ... women drinking and smoking' (bad). A similar sentiment was echoed in a Bradford focus group by Nadia, an Iranian woman who had been settled in the UK for decades and now volunteers at a refugee and asylum seeker group. She said that perhaps it was good that the Go Home van scared some people:

Nadia: But I think sometime maybe it's good. Why I say that? I used to have a friend, and I haven't seen her for years, she was Asian, Pakistani, she married another Asian, it took them years to call them here to get married, marriage took only 3 days, he used her 3 days and after third days said, 'I only married to come to this country', and he just vanished. After 2 days they can't find him, so if for people like that I think it's good.

(Bradford Focus Group, conducted by Hannah)

Though Nadia's example might seem to be more closely concerned with the abuse of immigration rules than Satwinder's, both women 
emphasise morality rather than law: 'for people like that I think it's good'. What does it mean to draw such moral distinctions? What are the consequences? And how might we think about and understand the nature of such distinctions? In this chapter we will explore these questions by:

1 extending the ideas presented in Chapters 2 and 3 on how moral judgements form part of a 'postliberal' politics, by discussing how our research participants positioned themselves within discourses of antipathy to (illegal) immigration

2 showing how many people judged as 'bad migrants' seek to portray themselves as valuable citizens deserving of respect and protection. They do this by pointing to other individuals who behave badly, and who thereby constitute the 'real' problem

3 identifying ways in which people targeted by immigration control, and anti-racist and migrants' rights campaigners, have opened up debates about solidarity, belonging and deservingness in alternative and sometimes politically ambivalent ways

4 discussing how these perspectives have been used to develop forms of resistance to government anti-immigrant policies and rhetoric.

\section{Devaluing migration}

There has already been a great deal of academic analysis of the vilification of certain, usually impoverished, groups of migrants in the context of the austerity agenda (Hall, 2015), electoral politics (Forkert, 2014), differentiated citizenship, nationalism and exclusionary discourses of belonging (Balibar, 2004; Lentin and Titley, 2011; Mezzadra and Nielson, 2013). Our aim in this chapter, however, is not simply to identify discourses of demonisation but to understand better the local and personal consequences of such discourses and some of the (often rebellious or contradictory) reactions to them.

The work of the migration researcher Bridget Anderson (2013) and the sociologist Imogen Tyler (2013) has provided us with a theoretical context for understanding this situation - a situation in which sharp distinctions are drawn between insiders and outsiders, and where belonging will always be precarious and conditional. Each scholar provides considerable food for thought on the links between the devaluing and segmentation of migrants into 'deserving' and 'undeserving' and the scapegoating of other social groups, notably those existing at the margins of an ever-retracting welfare state: 
benefits claimants, homeless people, single mums, sex workers and people with alcohol and drug dependency.

For Anderson, modern nation states are imagined as 'communities of value'. By this, she is referring not so much to 'British values'-type debates ${ }^{1}$ but to the ways in which some citizens are seen to matter - to be of value - because of acting and existing in good and proper (valuable) ways. These 'good citizens' who are envisaged as 'lawabiding and hard-working members of stable and respectable families' (Anderson, 2013: 3) are then positioned by government, media and public discourses as being in need of external protection from NonCitizens (foreigners and migrants) and internal protection from Failed Citizens ('benefit scroungers', paedophiles, rioters, criminals, etc.) (Anderson, 2013: 4). However, in reality, citizenship - even for the 'good citizen' - is not a natural and secured right: it is always a contingent relationship between a state and an individual, held open and differentiated along lines including race, class, gender, sexuality, disability and employment status (Anderson, 2013).

Anderson also argues that the recent waves of anti-immigrant hostility have relied on notions of a 'fantasy citizenship', in which new 'rights' - such as the 'right' to rent and the 'right' to work - have been named in public policy as if these actually mean something for national citizens (rather than being dependent on economic means, education and skills, or discrimination). According to Anderson (2015), the purpose has been to strengthen distinctions between those who hold national citizenship and those who do not. In other words, 'fantasy rights' conjured up by the state rely on the exclusion and demonisation of others. Moreover, this scapegoating operates within both neoliberal and postliberal frames which value (in a moral sense) those citizens who create exchange value. That is, those who are productive and aspirational (as good neoliberal subjects), and/or who fit conservative social norms of good behaviour (as good postliberal subjects), bearing in mind that even such behaviour may not be

\footnotetext{
${ }^{1}$ Claims to 'British values' have dominated debate about belonging and citizenship in Britain during the period of this study. They are often vague and disputed - particularly the idea that such values are exclusively British, or have been maintained historically or universally by Britain but are defined, for example, in the guidelines for how such values must now be taught in schools, as values of 'democracy, the rule of law, individual liberty, and mutual respect for and tolerance of those with different faiths and beliefs and for those without faith' (Ofsted, 2015: 36; see also House of Lords Hansard, 2014).
} 
enough given postliberal pessimism about cultural difference (see Chapter 3). Such framings have little use for those who are deemed economically unproductive or are seen to be unable to adapt to living in British society (learning English, etc.) - and they are often framed as a burden on limited resources. This is what Gavan Titley and Alana Lentin (2011) term 'good vs. bad diversity'. The bad migrant is located within a neoliberal frame that holds individuals (their morals, character and behaviour) responsible for poverty and inequality rather than structures and institutions (Rose, 1999). Social problems are passed off as the responsibility of individuals, and state intervention focuses on individual self-improvement and criminalisation rather than structural change.

It is important to note that these classifications are also highly gendered. Anderson's 'good citizen' combines the good behaviour expected of the modern liberal subject with traditional gender roles (the dutiful wife, the loving mother, the protective and providing husband - as we saw in Nadia's comments above, and Sara's reactions discussed in Chapter 1). At the same time the 'Non-Citizen' and the 'Failed Citizen' are depicted as uncivilised and parochial, epitomised by the caricature of the immigrant who has too many children in order to manipulate the welfare benefits system (Anderson, 2013: 7).

In her book Revolting Subjects (2013), Imogen Tyler identifies the affective and embodied dimensions of these characterisations of the modern state as reliant on the production of 'abject subjects' such as Travellers, asylum seekers and unemployed youth (2013: 4), who are identified as outsiders, so that others can be considered insiders. Tyler argues that, by producing disgust and repulsion towards a set of people who are made to seem abject ('revolting subjects'), governments encourage populations to align themselves as 'good citizens' against these 'revolting subjects', and thereby the limits of their own access to rights and citizenship are obscured. In developing these ideas, Tyler draws on the psychoanalytic concept of abjection, in particular Julia Kristeva's Powers of Horror (1982) - whereby the abject is a threat to meaning, identity and the social order, breaking down the distinction between self and other. A response to the abject is hatred and disgust. Kristeva had developed these ideas to understand xenophobia in Strangers to Ourselves (1991) as the "prickly passions aroused by the intrusion of the "other" in the homogeneity of ... a group' (Kristeva, 1991: 41). The 'other' then functions as a 'constitutive outside': people define their belonging by contrasting themselves with the 'other' or 'outsider' who does not belong. If we consider this in relation to postliberalism (as discussed in Chapter 3), this can help us understand the impulse of policy-makers to pay 


\section{Go home?}

attention to these sorts of 'prickly passions' about immigration, rather than cold statistics about the benefits of immigration to the economy. The performance of coercion, as discussed in Chapter 2, is seen as an effective way of drawing attention to an outsider against whom people can define themselves, in order to feel more securely 'inside' the nation.

In the following discussion, we consider the ways in which some migrants and people from racially minoritised backgrounds responded to Home Office immigration campaigns by talking about and devaluing 'others' in order to legitimate their own presence. We explore how people who feel devalued may use and reinforce pre-existing social classifications and divisions in order to gain value and respectability for themselves, and legitimise their own claims to citizenship. In particular, we consider the manner in which they make use of distinctions between types of migrants or migration in their interactions with others in order to escape the kinds of disgust associated with groups maligned by dominant discourses.

\section{Deserving citizenship and dis-identifying from the 'bad' migrant}

A number of people we spoke to in the course of our research framed their own right to be in the UK (i.e. their sense of themselves as deserving citizens or good migrants) through recourse to narratives about work ethics and economic productivity:

Kirsten: Do you feel that [your organisation] is affected by negative media coverage and if so how?

Nader:Yeah, [our organisation] of course is affected by it because all the members - or most of them ... are failed asylum seekers ... The media ruined the reputation of asylum seekers in this country. They made the asylum seeker look like he is a criminal. Asylum seeker is not a crime ... We are innocent people who came here to seek refuge. Just give us refuge. Give us our rights. Our rights is not money. We don't want money. We don't want support, we don't want housing. Give us the right of at least to work and I will support myself and all - I think most of the asylum seekers would do the same ... I will work, I will rent, I will pay my contribution to the community, I will pay my tax, I will pay my rent, I will pay my Council Tax, I'll buy a car, I'll get a job, I'll be helpful for the community I'm living in. I will integrate.

(Coventry Activist Interview, conducted by Kirsten) 
Here Nader, an activist and an asylum seeker who was not allowed to work, was responding defensively to a news story in the Coventry Telegraph about the 2014 Immigration Bill (now law), and how immigration rhetoric and legislation position immigrants as not contributing to society. As part of this emphasis on 'making a contribution', he appeals for recognition and empathy on the basis of independence from state welfare. For example, when describing an encounter with a woman who believed that refugees were given free phones, cars etc., Nader emphasised that they were not in the UK for the welfare system:

We are not here to seek support, we are here to seek asylum, we are here to seek refuge, a safe place to live, but we can depend on ourselves and contribute to the community and work and pay our contribution.

(Coventry Activist Interview, conducted by Kirsten)

Some research participants used this 'model migrant' stereotype of hyper-productivity to validate themselves, but they also used it as a way of resisting a dominant narrative that derides 'illegal immigrants' as burdens on the taxpayer (Yukich, 2013). Neesha, quoted below, is a second-generation Indian woman who was defending 'illegal' immigrants as part of her wider rebuttal of the racism of Home Office immigration campaigns. However, her defence of 'illegal' immigrants relied on the characterisation of some white British people as lazy and dependent on benefits. Her comments contained expressions of disgust for the assumed characteristics of the 'benefit scrounger' (namely idleness, smoking, drinking and use of drugs):

Neesha: White people don't work as hard as our own do ... I think the government are emphasising the fact that it's illegal but not the fact they [immigrants] are working. The message they should actually show is that this person is working, not that they are sitting at home, smoking god knows how many fags a day and drinking cans of beer and on drugs ... why don't they focus on the people who've been signing on and doing sweet ' $F$ ' anything for 20 years who say yes, I'm not gonna work because I'm better off on benefits? They are targeting people who are working, they may be illegal but they are working, they are contributing.

(Ealing and Hounslow Focus Group, conducted by Sukhwant)

Neesha's reaction suggests the degree to which government immigration campaigns are inciting and exacerbating division, pitting 
excluded groups against each other. A defence of one excluded social group (the 'illegal immigrant') deploys moral judgements about the presumed lifestyles of other excluded groups (the benefit claimant). However, this is a dangerous position. Arguments about hard work, entrepreneurship and non-dependence on the state can also potentially play into the xenophobic charge that immigration is undercutting the 'white working class' by working in exploitative conditions that British people would not accept. This is the basis of many anti-immigration messages (e.g. Field, 2014) and was one mobilised to great effect during the 2016 EU referendum campaign.

'Good citizenship' is also seen to be embodied within certain behaviours, while other behaviours are seen as marking one as unfit for being a responsible citizen. Sometimes even smoking cigarettes and drinking alcohol could become potent signs of the undeserving citizen, and participants made assumptions about other people's immigration status solely on the basis of perceived 'bad behaviour', as Satwinder does here:

There are a lot of men ... in the area that ... are paying money and coming here. And they are now in situations where they are taking drugs or alcohol. They are getting high and there are young women that are also getting into trouble or getting into bad ways. And this is a problem. So when people no longer have a visa, they should go.

(Ealing and Hounslow Focus Group, conducted by Sukhwant)

As with other participants we have heard from in this chapter, Satwinder associated undeserving groups with criminality, illicit sex, theft and, in extreme cases, terrorism. Historically, these behaviours have been associated with people in vulnerable or dependent positions: 'racialised others, women, slaves, children, beggars, and those who were not able-bodied or those of "unsound mind" ' (Anderson 2013: 96). The good liberal citizen has also historically been framed in relation to a particular temperament, defined against the less desirable temperament of the migrant or the colonised other, who are often depicted as irrational, hot-tempered and superstitious. Such characterisations of temperament were also apparent within our focus group discussions where people who were seen as undeserving of the right to be in the UK were characterised as bad people not only in relation to a lack of productivity but also in relation to personality flaws, notably insincerity, manipulation, unreasonable behaviour and a bad temper. 
Eastern Europeans were repeatedly singled out and characterised as being deceptive. For instance, Zimbabwean participants in a focus group in Glasgow described Eastern Europeans as 'naughty', 'stealing and fighting' and 'begging', and argued that 'they don't work' and are 'playing the system'. Some participants in the Bradford focus group of refugees and asylum seekers from around the world were anxious to know what had been said about them in the focus group with Eastern European migrants. Yet in the focus group with Eastern European migrants, the claims to respectability, and attempts to distance oneself from disrepute, were very similar:

Hannah: I just wanted to ask what you think of that picture [of the Go Home van]?

Lukas: Actually [what] they are saying is, they don't feel like illegal here now we are in the Eastern European, eastern Europe, and we are legal, can work, and ...

Hannah:Yes, no, and I'm not saying that that's - for you ...

Lukas: They say just that these people supposed to go home, who is stealing, making problems, who are not working ... They are here for the work, to work, that's why they come here. She would do any job, she can't get job, she would do any job.

(Bradford Focus Group, conducted by Hannah, English-Slovak interpreter (Lukas))

Through the interpreter, this group of mainly Slovakian nationals (and EU citizens) made clear that they were aware of their citizenship rights in the UK, and that the injunction to 'go home' could not now be legally applied to them. Nevertheless, they still felt their ability to be seen as part of the 'community of value' as somewhat tenuous. They insisted on their desire to work and provide for themselves; acting as 'guardians of good citizenship' (Anderson, 2013: 6), they contrasted themselves with others, 'who is stealing, making problems, who are not working'. Similarly, some of the women that participated in the Ealing and Hounslow focus groups (of South Asian, African and Caribbean origin), suggested that Eastern Europeans were benefit cheats. It seemed that for some participants, the simple act of accessing one's legal entitlement to welfare benefits could be construed as fraudulent behaviour.

As Bradford and Ealing and Hounslow activists noted, many of these distinctions settled on top of the unfinished business of historical and contemporary political tensions within local communities (see also Chapter 4). In particular, they pointed to existing schisms 
between Sikhs and Muslims, between Asians and newly arrived Roma communities, between Asians and Somalis. These communitarian schisms were criss-crossed by numerous nation and local dynamics. For example, there were also the divisive tactics of Muslim fundamentalist mobilisations on the one hand and of the government's 'war on terror' agenda on the other. These dynamics played out alongside racialised class politics which stirred up resentment among poor white communities by pointing to 'immigrants' in general as the reason for lack of jobs, housing or prospects, while long-term disinvestment in post-industrial areas such as Bradford, Coventry and elsewhere was ignored (see also Haylett, 2001).

We also heard how assumptions about migrants being morally unsound could be a part of institutional decisions. In the following extract, John, a Birmingham migrant rights advocate, talks about the culture of disbelief within the asylum system and social care responses to asylum seekers and refugees, by describing his struggle to get a mental health assessment for an Iranian asylum seeker who was suffering post-traumatic disorder due to experiencing torture and sexual abuse in prison:

John: We were asking for a mental health assessment [of an asylum seeker] and Mental Health Services told him, without even having met the asylum seeker, that 'we'll meet with him but he's probably putting it on for his asylum claim'.

(Birmingham Activist Interview, conducted by Kirsten)

The perception that asylum seekers are faking or exaggerating mental health problems in order to support their asylum claims, in line with media stereotypes of the 'bogus asylum seeker' (Smart et al., 2005; Thomas, 2012), has real consequences: a UK citizen with symptoms of mental distress is seen to be in genuine need, but the signs of pain or emotional distress for an asylum seeker are suspected of being fabricated.

You will now have a sense of the ways in which distinctions between migrants can be drawn in everyday conversations. However, we felt that it was not sufficient to conclude that people have simply internalised and are reproducing dominant messages about the untrustworthiness of (other) migrants, refugees or asylum seekers. One way of understanding what can be at work in these discourses is to consider them in relation to the sociologist Beverley Skeggs's work on value and respectability $(1997,2014)$. In particular, we think it worthwhile to consider Skeggs's exploration of the ways in which workingclass women from the North-East of England attempted to distance 
themselves from their class by talking down other groups. Here is one of Skeggs's research participants talking about other working-class women:

You know, you see them walking around town, dead fat, greasy hair, smelly clothes, dirty kids, you know the type, crimplene trousers and all, you know the type, I'd never be like that.

(Therese, quoted in Skeggs, 1997: 83)

Such responses exist in a context where being working-class is seen both as shameful, especially when applied to women, 'as used to signify everything that is dirty, dangerous and without value' (Skeggs, 1997: 74) and as a form of judgement and categorisation, 'trying to fit people into pigeonholes' as one of her respondents put it (Skeggs, 1997: 77). The disparagement of others was a way in which the women could defend themselves from a dominant discourse that devalues them, and yet they could not entirely disconnect themselves from others because of the material reality of their class position.

Unsurprisingly, the claims for legitimacy we heard tended to be couched within the terms of the dominant discourse. Yet, because of the racialisation of discourses on immigration (see Chapter 6), the continued prevalence of racism and the material realities of the research participants' class positions, it was not necessarily possible for the people making these claims to escape the group identities that they appeared to be talking down. As we will discuss in the next section, a number of people we spoke to in the course of our research also pushed against these deserving/undeserving distinctions.

\section{'Values beyond value'? Resisting anti-immigrant messaging}

While some people we spoke with expressed their claims to belonging through appeals to individualised neoliberal values of productivity and aspiration, others resisted these values and reached instead for - to use Skeggs's phrase - 'values beyond (exchange) value' (2014). Seemingly banal comments about warmth, hospitality and love could be profound in a context where migrants were struggling against the daily strictures of immigration controls that are material, social and emotional. The following participants highlighted examples of everyday acts of kindness that had impacted positively on their own or other migrants' sense of self-worth, serving to resist or subvert dehumanisation: 
Mary: And what I can say, it's a tough, very, very tough, asylum life here, it's horrible ... but I'm lucky ... I find warm and honest friend, British, in Birmingham ... well I can say I like it, my city, and I love the British because they have honest people and good friend, very, very good friend, and look after me ... I appreciate everything single one who support me, this city.

(Birmingham Focus Group, conducted by Kirsten)

Wendy: We've had other occasions where someone's arrived and have spoken hardly any English and neighbours ... they bring them down to our organisation. They don't particularly want to get involved themselves but they just happen to know that we're there ... and they turn up with them and say, 'We thought that they should know about your organisation.' So there are some marvellous acts of kindness actually.

(Bradford Activist Interview, conducted by Hannah)

Adam: There's one very interesting thing I find about Cardiff, you walk on the streets and people tell you 'good morning' in Cardiff ... A woman told me 'good morning' this morning as well ... It's good for you to be around good people. That someone to tell you 'good morning, good morning' it's good.

(Cardiff Focus Group, conducted by Roiyah)

In a sense these thoughts and experiences are part of an attempt to rehumanise social relations against a torrent of government interventions that are profoundly dehumanising. Some people went further than describing existing acts of kindness, to suggest that a wholly different type of politics was needed:

Mosef: If I was gonna change that [Go Home van] poster I'd have a poster saying love is the strongest emotion. Love don't fear.

(Cardiff Focus Group, conducted by Roiyah)

Lukas: He say it's no matter if you from Bangladesh, if you from India, or Czech Republic or Slovakia, with love! You can treat everything. You love somebody - or - treat somebody with love. It's completely different. There wouldn't be things like this. (Bradford Focus Group, conducted by Hannah, English-Slovak interpreter (Lukas))

More practically perhaps, participants at the Glasgow focus group suggested that anti-immigrant sentiment could be tackled by, for 
instance, creating space for people to tell their stories and be heard by decision-makers, forcing politicians into more empathetic responses:

Rose: I think if you can call that Theresa May, say to come down here [thumps table], we want to talk to her nicely, not badly, nicely. Immaculate: Or to ask her what do you think about people who left their families more than ten years ago ...

Rose: I would suggest you have the next plan maybe in the future, you publish this information, article, and public event, I would suggest would be better if you invite some maybe speaker or some other people to share their stories, quite important and very live for people, make a very big impact on people.

(Glasgow Focus Group, conducted by Emma)

Other parts of the same focus group conversation provided insights into possible ways out of this all-pervading anti-immigrant rhetoric. These surfaced when some in the group wanted to distinguish themselves from the alcohol and drug users with whom they shared hostels and were challenged by another participant:

Rose: I says to them, 'Please do something, put us in grades not to put asylum seekers together with the alcoholics, we are not like them, we don't do wrong to people, we are nice people.'

Immaculate: Not just the drug addicts they are all just alcoholics. Rose: Both, drug addicts and alcoholics.

(Glasgow Focus Group, conducted by Emma)

As with many of the examples discussed in the previous section, Rose and Immaculate seemed to judge the addictions of other residents, while simultaneously making a bid not to have their hard-fought-for asylum claims tarnished by the behaviour of other hostel residents. However, in response to this, Sirvan observed that passing moral judgements on other people's problems or circumstances involves validation of the same logic that informs Home Office anti-immigrant campaigns:

Sirvan: See my understanding, if you make, say we are different with them, so that's the base of the things that they do, they said, 'We are better than you' ... See if we do this it's discrimination, make you ... that's why they do discrimination against us, they say 'we are better than you', if you say 'we are better than other people' that's the same principle.

(Glasgow Focus Group, conducted by Emma) 
For Sirvan, asylum seekers saying 'we are better than you' to addicts is a repetition of the same pattern of discrimination whereby asylum seekers and refugees are treated as lesser humans by others. Similarly, while discussing an image of the Go Home van, Grace problematised the distinctions being made by her peers between migrants arriving through different routes and with different visa statuses:

Grace: Even some of my friends said that immigrants should 'go home'. They say 'I'm not talking about you, but let them go - the Eastern Europeans'. It's not like that, they can't say they're not talking about me, they are talking about me - we are all in the same boat, you can't just say 'you're okay' [and others are not].

(Bradford Feedback Session, conducted by Hannah)

Echoing Martin Niemöller's famous poem 'First they came ...' (Niemöller, 1946), Grace argued that, if the Home Office started by targeting irregular migrants, they would soon come after others. She suggests the possibility of solidarity between different groups of people who are treated as a social problem, rather than the approach of seeking a more abject group against whom to define oneself as more deserving.

Interestingly, many participants emphasised the connection between generating alternative values and pro-immigrant protest. The starting point for some participants was a stand against apathy - the need for people to actually believe that they can change the terms of the debate. Within most of the focus groups, participants talked at some point about the need for local people to self-organise in order to defend the migrants in their area. For instance, while talking about the impact of the poster campaigns in Glasgow, Sirvan made the following point:

we could stop this campaign ... encourage people to participate in the community and their organisation to fight for our rights.

(Glasgow Focus Group, conducted by Emma)

In Bradford, on learning of the Go Home van for the first time, Aminata also suggested alternative direct action that might engage in - and shift - the terms of the performative politics of immigration control, by putting the ideas of home and belonging in question and erasing the illusion of a simplistic answer to immigration debates:

Aminata:Yes, I said like these people doing it, their van, 'go home'. Like the Red Cross or the Refugee Council or World Health 
Organisation, they can make their own van to protect the asylum seekers, to say, 'I don't have home'.

(Bradford Focus Group, conducted by Hannah)

\section{The values base of pro-immigrant protest}

During our research we observed many calls to action, street protests and demonstrations. These ranged from spur-of-the-moment activities to those involving detailed planning and preparation; from tactical engagements with the politics of performance to more traditional actions rooted in histories of labour and other liberation movements; and from those engaging with neoliberal logics of economics to postliberal logics of morality, to those which suggested an alternative logic of social justice.

Alongside, and linked to, these on-the-ground activities, at a national level, the Joint Council for the Welfare of Immigrants and Movement Against Xenophobia's '\#IAmAnImmigrant' campaign brought together myth-busting information and individual testimonies in the runup to the 2015 General Election (see also Chapter 6). The campaign comprised photographs of fifteen people introducing themselves and the contribution they had made to society, and declaring themselves to be immigrants, displayed on 440 billboards across the London Underground and another 550 at railway stations across the country. The popularity of the campaign was demonstrated by the fact that over $£ 50,000$ was raised through crowd funding within a matter of weeks to fund this public advertising. Thousands of people have now used the hashtag to share photographs of these posters, which carry short testimonies of people who at some point migrated to the UK and have been involved in improving the quality of others' lives - a nurse, a fireman, a teacher and a lawyer are among those depicted. In addition, many members of the public have taken up the invitation to add their own story to their website in a similar format. ${ }^{2}$ In putting a 'human face' to the figure of the immigrant, this campaign has been seen as important for rehumanising the debate about migration and emphasising the contributions being made by migrants in relation to the economy but also in relation to civil society and social welfare.

We would also suggest that there are limits to how far such a framing challenges the underlying logic of a distinction between good

${ }^{2}$ See www.iamanimmigrant.net/my-story. 


\section{Go home?}

and bad migrants, or deserving and undeserving citizens that we have discussed in this chapter. It figures the poster boys and girls of the campaign as human and relatable (see Chapter 6), but on the basis of their contribution to society, rather than their existence as fellow human beings. Nevertheless, it is a pragmatic response to the performative politics of stigmatisation, using the same tools of performance to attempt to create a (post?)-political space in which the consensus that might be reached is one about the human face of 'the immigrant'.

Elsewhere, we have seen that while the Westminster postliberal consensus has seemingly rejected the neoliberal idea that the economic contribution of individual migrants has any weight in political debate (see Chapter 3), there are ways in which campaigns based on economic arguments have influenced aspects of the 'hostile environment'. Hot on the heels of the decision not to extend Operation Vaken, there was stiff opposition to the coalition government's 2013 proposal to introduce $£ 3,000$ 'visa bonds' for applications by those entering the UK from six specific countries - India, Pakistan, Bangladesh, Sri Lanka, Nigeria and Ghana - identified as at 'high risk' of overstaying their visa. Jasjit, an activist in Ealing and Hounslow (interviewed by Sukhwant), explained that these proposals were dropped because a number of government departments - including the Foreign and Commonwealth Office, the Department for Business, Innovation and Skills and the Department for Communities and Local Government - expressed their opposition, and the then Deputy Prime Minister Nick Clegg threatened to veto the plans. Politicians who had otherwise been silent on the development of the Home Secretary's 'hostile environment' raised concerns about the implications for a government courting trade relations with India and Nigeria. While the attempt to discuss migrant contributions to the national economy have lost favour in political debate, within diplomatic circles it still seems that money talks.

In more on-the-ground political protests, some of our participants had themselves been involved in demonstrations. In response to an image of people opposing the poster campaign in Glasgow, Immaculate noted that people subject to immigration rules are at the forefront of protests against the government's communications:

Immaculate: At the moment there's a group of asylum seekers and refugees they're actually going to the Home Office campaigning in front every week, they have just decided they're not any organisation to support them, they're doing it on their own, they are doing it every week now, and they said they won't stop. They will 
be there every week in front of the Home Office, whether it's one or two turn up, they are going to do every week.

(Glasgow Focus Group, conducted by Emma)

Manoj, a London activist who works for an anti-racist advocacy project (interviewed by Sukhwant), described how the contributions of immigrants to the economy were made visible in a more oppositional and grassroots-led way, in the community resistance of 2013 that came to be known as 'the Chinatown shutdown'. After Home Office Enforcement teams increased the intensity of their 'fishing raids' looking for migrants working illegally in businesses in London's Chinatown, concerns were raised about both the racial profiling of the Chinese community and the impact on Chinese businesses. This gave rise to a broad-based resistance that included businesses, anti-racists and cultural organisations, whereby staff in restaurants throughout Chinatown closed their businesses and took to the streets to protest about the heavy-handed immigration raids, on 22 October 2013.

Other activists sought to reorient the discussion to address those issues that are veiled by anti-immigrant rhetoric because, as the political scientist Shamit Saggar (2004) has argued, immigration is often a proxy for other concerns. As discussed in previous chapters (see especially Chapter 2), we held a focus group in Dagenham with people who identified themselves as British National Party (BNP) supporters. Their discussion suggests how immigration becomes the empty signifier into which people pour a range of concerns and complaints, such as those relating to housing needs, cuts to the National Health Service, health and social care, local authority accountability and the contracting out of local council services. Notably these were all concerns about the distribution and management of public goods. Moreover, it was clear from the speakers at a September 2013 demonstration outside the Glasgow reporting centre (Emma's fieldnotes), that focusing political resistance back on to jobs, housing and health has been an important angle for counter-mobilisations. This was also the cornerstone of the response by Gary, a leading trade union activist in London, who argued that counter-messaging should focus on getting behind the immigration façade and focusing on those other concerns:

Gary: We're trying to come up with a project which looks at trying to change the nature of the debate that we have around migration to focus instead on, if you like, shifting the blame. So migrants are getting blamed for various things and people see migrants as 
a problem. So what you do is try and come up with ways of shifting the blame for migration from migrants to other people ... [For example] it's not the fault of migrants that there are these problems. It's the fault of employers. Because what employers are doing is using migrants to exploit their labour. It's not the fault of migrants because there's problems about access to local services, for two reasons. One, migrants are providing local services and it's easy to find [evidence for that]. And secondly ... services are under pressure because they're getting cut ... Because from our perspective, migration is a proxy issue. Yeah, there's a level of racism there and xenophobia but the real concern about people when you hear them talk about migration is they don't just talk about immigrants, they talk about immigrants in relation to getting jobs, getting access to services, getting housing.

(London Activist Interview, conducted by Sukhwant)

Gary suggested that solidarities between newly arrived migrants and racially minoritised citizens who are settled in Britain will inevitably arise because the latter will be affected by the same 'hostile environment', as landlords and employers decide to 'play it safe' by discriminating against non-white applicants to avoid falling foul of the Immigration Act 2014 and Immigration Bill 2015-16, which make private landlords liable for checking the visa or settlement status of their tenants. However, he argued that, beyond this coincidence of concerns, solidarities need to be actively mobilised and produced by identifying shared experiences of exploitation and material conditions across racial divides.

Gary: At the moment, what you have is very similar kinds of exploitation but this barrier that comes down ... well yeah, you're getting exploited but that's fine because you're a migrant, I'm getting exploited but that's not okay because I'm a Brit ... One of the potentials for me is ... to [show] people that their stories are very similar.

(London Activist Interview, conducted by Sukhwant)

Gary argues for changing the conversation from one that continues to be located within the neoliberal frame of productivity to one that counters anti-immigrant sentiment from an anti-racist and socialist perspective. Others recognised the value of revisiting histories of racism and colonialism to revive historical solidarities, particularly within local areas where anti-racist mobilisations have been linked to a defence of immigration and public welfare services (see also Chapter 4). 
Participants in many of our focus groups made connections between the treatment of asylum seekers and the legacy of colonialism, particularly the double standards in terms of the presence and treatment of British people in other countries, as compared to the hostility faced in the UK:

Parveena: I'm from India, they ruled my country for 250 years, and they have taken everything. I wouldn't say that all our population are coming here, people who are in need are coming here, then why don't they give the hospitality for the people?

(Birmingham Focus Group, conducted by Kirsten)

Amadou: In other parts of the world, in the foreign countries if these people or any foreign people come, they respect them. And they treat them more than as a guest.

Mohammed: Why don't they treat us the same?

(Birmingham Focus Group, conducted by Kirsten)

When participants conceptualised issues in these ways, it seemed to us that they were moving beyond either the neoliberal (economic) or postliberal (moralistic) framing of immigration. In a way they were politicising and historicising the valuing of warmth, hospitality and love described earlier by Mary, Wendy, Adam, Mosef and others. If there is a moralistic element to this politics, it is not the call to 'respectability' of postliberalism but a call for fairness and justice, for taking into account the historical injustices of colonialism and capitalism that have led to the current geopolitics of migration.

As with the women who came together at Southall Black Sisters to protest against immigration enforcement raids (see Chapter 4), it was clear from the local area studies that voluntary-sector contexts, or simply spaces to discuss these issues, could facilitate the ability to think of 'values beyond [exchange] value', to return to Skeggs's term, and build networks of solidarity that could help to translate these values into action, and counter the tendency to pit groups of people against each other.

\section{Conclusion}

In this chapter we have argued for the importance of contextualising narratives of deservingness by situating them within wider social settings. Our findings suggest that, as migration is devalued, claims to economic productivity are increasingly used to validate citizenship 


\section{Go home?}

and to talk down other groups, so that work, aspiration, productivity and conformity with socially conservative behaviour codes have increasingly become proxies for nationalism, rights and belonging. In addition, the recourse to a fantasy citizenship based on a continually recalibrated array of distinctions and entitlements is a way of negotiating and often sidestepping existing differentiation in citizenship on the basis of race, gender, sexuality, disability and class.

Our research has also shown that anti-immigration messages from government and the media are not simply internalised. Some of the people we interviewed resisted anti-immigration messaging by countering the imperative for people to pit themselves against each other on the basis of their immigration status or nationality. The organisations they belonged to often created the space for these discussions to take place. Most importantly, recoupling debates on racism and immigration control seemed to help to challenge distinctions between deserving and undeserving migrants, as in the connections between colonial histories and the current geopolitics of migration control drawn by Parveena, Amadou and Mohammed. Protest actions both real (the SBS street protest, the Chinatown Shutdown, \#IAmAnImmigrant) and imagined (the 'I don't have a home' van Aminata describes, the 'fight for our rights' Sirvan imagines) can help create solidarity across national, ethnic and class lines. The appeal to recognition of the worthwhile character of (some) migrants as productive neoliberal subjects of the \#IAmAnImmigrant campaign contrasted with the more traditional trade-union-inspired politics of a withdrawal of labour and demonstration of power in the Chinatown Shutdown. Yet both can be seen as attempts to counter the postpolitical and postliberal politics of immigration control (see Chapters 2 and 3) with alternative performances. Coupled with the attempts to refigure discussions to recognise colonial and labour histories, as many of our participants described and attempted, this has the potential to be a powerful antidote to the performances of toughness, threat and exclusion which currently dominate public debates on immigration and its control. The increasingly controversial nature of such debates shows the importance of both creating networks of solidarity and articulating such alternative values - and as publicly as possible.

\section{References}

Anderson, B. (2013) Us and Them? The Dangerous Politics of Immigration Control, Oxford: Oxford University Press. 
Anderson, B. (2015) Keynote at Mapping Immigration Controversies conference, University of Warwick, 10 June, www.youtube.com/ watch? $v=n N P M K Z R h v g o$ [last accessed 22 May 2016].

Balibar, E. (2004) We, the People of Europe? Reflections on Transnational Citizenship, Princeton: Princeton University Press.

Field, F. (2014) 'The lower classes have serious, and justifiable concerns about mass immigration', The Spectator, 8 July, http://blogs. spectator.co.uk/2014/07/the-government-must-address-the-effectof-mass-immigration-on-poorer-voters/ [last accessed 22 May 2016].

Forkert, K. (2014) 'Who's being ignored when politicians are claiming they are listening to concerns about immigration?', Mapping Immigration Controversy, 2 December, http:// mappingimmigrationcontroversy.com/2014/12/02/whos-beingignored-when-politicians-claim-they-are-listening-to-concernsabout-immigration/ [last accessed 22 May 2016].

Hall, S. (2015) 'Focus: Migration and election 2015', Discover Society, 17, 1 February, http://discoversociety.org/2015/02/01/focus-migrationand-election-2015/ [last accessed 22 May 2016].

Haylett, C. (2001) 'Illegitimate subjects?: Abject whites, neoliberal modernisation, and middle-class multiculturalism', Environment and Planning D: Society and Space, 19(3): 351-70.

House of Lords Hansard (2014) 'Schools: British Values', 754, 12 June, https://hansard.parliament.uk/Lords/2014-06-12/debates/ 14061243000356/SchoolsBritishValues [last accessed 22 May 2016].

Kristeva, J. (1982) Powers of Horror: An Essay on Abjection, trans. L.S. Roudiez, New York: Columbia University Press.

Kristeva, J. (1991) Strangers to Ourselves, trans. L.S. Roudiez, New York: Harvester Wheatsheaf.

Lentin, A. and Titley, G. (2011) The Crises of Multiculturalism: Racism in a Neoliberal Age, London: Zed Books.

Mezzadra, S. and Nielson, B. (2013) Border as Method: or the Multiplication of Labour, Durham, NC: Duke University Press.

Niemöller, M. (1946) 'First they came for the socialists ...'. For full text see United States Holocaust Memorial Museum: www.ushmm.org/ wlc/en/article.php?ModuleId=10007392 [last accessed 19 June 2016].

Ofsted [Office for Standards in Education] (2015) School Inspection Handbook: Handbook for Inspecting Schools in England under Section 5 of the Education Act 2005, Manchester: Ofsted, www.gov.uk/ government/publications/school-inspection-handbook-fromseptember-2015 [last accessed 19 June 2016].

Rose, N. (1999) Powers of Freedom: Reframing Political Thought, Cambridge: Cambridge University Press. 
Saggar, S. (2004) 'Immigration and the politics of public opinion', The Political Quarterly, 74 (s1): 178-94.

Skeggs, B. (1997) Formations of Class and Gender: Becoming Respectable, London: Sage.

Skeggs, B. (2014) 'Values beyond value: Is there anything beyond the logic of capital?', British fournal of Sociology, 65 (1): 1-20.

Smart, K., Grimshaw, R., McDowell, C. and Crosland, B. (2005) Reporting Asylum: The UK Press and the Effectiveness of PCC Guidelines, London: ICAR, http://www.crimeandjustice.org.uk/sites/ crimeandjustice.org.uk/files/ReportingAsylum.pdf [last accessed 22 May 2016].

Thomas, A. (2012) 'Asylum seekers continue to be stigmatised by the British press', The Guardian, 31 October, www.theguardian.com/ media/2012/oct/31/asylum-seekers-stigmatised-british-press [last accessed 22 May 2016].

Tyler, I. (2013) Revolting Subjects: Social Abjection and Resistance in Neoliberal Britain, London: Zed Books.

Yukich, G. (2013) 'Constructing the model immigrant', Social Problems, 60 (3): 302-20. 